\section{DIGITAL COMMONS \\ @ UNIVERSITY OF SOUTH FLORIDA}

\section{ABO: Interactive Journal for Women in the Arts, 1640-1830}

Volume 2

Issue 1 Volume 2.1 (Spring 2012): Open Access

Article 17

2012

\title{
Multiplying Worlds: Romanticism, Modernity, and the Emergence of Virtual Reality, by Peter Otto
}

Stacey Kikendall

University of New Mexico

Follow this and additional works at: https://digitalcommons.usf.edu/abo

Part of the Dramatic Literature, Criticism and Theory Commons, Educational Methods Commons, Feminist, Gender, and Sexuality Studies Commons, and the Literature in English, British Isles Commons

\section{Recommended Citation}

Kikendall, Stacey (2012) "Multiplying Worlds: Romanticism, Modernity, and the Emergence of Virtual Reality, by Peter Otto," ABO: Interactive Journal for Women in the Arts, 1640-1830: Vol.2: Iss.1, Article 17. http://dx.doi.org/10.5038/2157-7129.2.1.16

Available at: https://digitalcommons.usf.edu/abo/vol2/iss1/17

This Reviews is brought to you for free and open access by Digital Commons @ University of South Florida. It has been accepted for inclusion in ABO: Interactive Journal for Women in the Arts, 1640-1830 by an authorized administrator of Digital Commons @ University of South Florida. For more information, please contact digitalcommons@usf.edu. 
Multiplying Worlds: Romanticism, Modernity, and the Emergence of Virtual Reality, by Peter Otto

\section{Keywords}

Modernity, review, Romanticism, technology, virtuality, visual culture

\section{Creative Commons License}

(c) $($ ) $\Theta$

This work is licensed under a Creative Commons Attribution-No Derivative Works 3.0 License. 
Peter Otto. Multiplying Worlds: Romanticism, Modernity, and the Emergence of Virtual Reality. New York: Oxford UP, 2011. \$110.00. xiv + 332 pp. ISBN 978-0-19-956767-6.

\section{Reviewed by Stacey Kikendall, University of New Mexico}

In his book, Multiplying Worlds, Peter Otto attempts to bring together traditional ideologies of Romanticism with the modern concept of virtuality. He argues that modern understandings of virtual reality first appeared during the Romantic period and uses various technologies, literary texts, and psychological apparatuses from the late eighteenth- and early nineteenth-centuries to support his assertion. He claims that new tensions evolved during this time because of the collapse between what he calls first-order realities and second-order realities. Otto defines "virtual reality" as the absence of reality or the idea that reality is a perceptual illusion that can be changed and altered by material, psychological, and or cultural apparatuses. This virtual reality can be constructed through technologies such as the panorama or the fictional worlds of literature. Ultimately, as his title suggests, the real world and the imagined or virtual world blend and blur into multiple worlds that can and do exist simultaneously. The problem is that I don't think many scholars would disagree with him, because his description of virtual reality sounds very much like the imagination - a concept traditionally and continually associated with Romantic era writers and thinkers. Even Otto uses as part of his argument the idea that what "gives life the potential...to be different" is what Romantics named "imagination or energy" (183).

In the past two decades, scholarship exploring vision and visual culture in nineteenth-century literature has exploded. Peter Otto definitely seems to be responding to this interest in some ways, and as a scholar interested in visual and popular culture and its utilization in the literature classroom, I found Otto's premise initially to be very exciting and promising. However, I rapidly found myself immersed in fairly traditional ideas of the Romantic imagination and the Romantics' ongoing interest in the difference/distance between the real and the imagined, or as Otto names them the actual and the virtual.

The book is divided into three sections, "From the Actual to the Virtual," "From Representation to Poiesis," and "Actuvirtuality and Virtuactuality." The first part addresses the panorama, the panopticon, and the Temple of Health and Hymen and the ways they simulate, shape, and engage people's perceptions of the real world as well as imagined worlds. The first chapter uses Caspar David Friedrich's painting The Wanderer above a Sea of Mists and Robert Barker's panorama to argue for the increased emphasis on representation and constructed observation. Otto argues that the wanderer in the painting, who is standing on a cliff looking out to the sea and a distant horizon, and the spectator at a panorama, who views a circular painting from a platform extended into the middle of a cylindrical building, share a kind of prospect view on the edge of reality. This illusion of reality challenges the nature of all perceptual worlds. The following chapter discusses Jeremy Bentham's Panopticon papers, which include not just the penitentiary but also a tavern and a sotimion, and the desire to change reality as opposed to simply simulating it. He explains that by immersing the inhabitants "... in a social fiction that rearticulates the relation between centre and periphery, and fostering experimental behaviour, the Panopticon constructs an emergent world rather than one based on pre-existing forms" (55). Otto then moves from the rehabilitative goals of the panopticon to an immersive "experience of ecstasy" in James Graham's 
Temple of Health and Hymen (62). Here, Graham's charlatanism emphasized the unreliability of the boundary between actual and virtual. These initial chapters seem to act primarily as examples of the ways Romantics imagined different realities, which is hardly a new concept.

The second part of the book focuses primarily on the ways the gothic inspires dream-like sensations, using Ann Radcliffe's novel The Mysteries of Udolpho, the Phantasmagoria, and Fonthill Abbey as examples. These are the most compelling chapters because he relies on close readings of textual media to assert that the gothic inspires people to react emotionally to a constructed, fictional reality. For example, he uses a scene in Udolpho where Emily is watching St. Aubert gaze at a portrait to highlight the series of gazes and the lack of contextual information for an accurate reading of the situation. The continual confusions and inability to recognize the real from the imagined lead the audience to "become co-creators of imagined worlds" with the author (103). Otto continues by positing that the phantasmagoria provokes audiences to astonishment despite the repeated reminders that the spectacles they are observing are simple illusions. He then turns to William Beckford's attempt to recreate the gothic emotional excess with an elaborate Christmas party, where he and his guests existed in a world separate from confining social strictures, and his estate Fonthill Abbey, which "composes a vast phantasmagoria, an extended gothic fiction" where "... Beckford is himself showman and audience, author and reader, shaping and being shaped by an environment he has created" (159). The last chapter in the section seems tangential by examining the figure of Satan and the imagined reality of Hell. Specifically, Otto argues that "radical artists and writers" use of Satan represents "themselves as creators of virtual realities," using Blake as a prime example (163).

The third part concludes his argument by exploring the ways in which the Romantics engage with the virtual, including authors such as William Blake, William Wordsworth, Mary Shelley, and Thomas DeQuincey. Using Blake's Jerusalem and his constructed religious mythology, Otto pays particular attention to the visual images and the freedom represented by the blurring of lines (literal and figurative) between the actual and virtual worlds. He then examines Wordsworth's representations of identity as both shaping and shaped by the environment, using the Aeolian harp, Brocken spectre, and "spots of time" as the most important metaphors. In his "spots of time," Otto argues, Wordsworth allows for moments where the actual world is eclipsed and the self "veer[s] from the given" (236). Next, he contends that Mary Shelley's creature is a "combination of synthetic and emergent behaviours often associated with the human (and which in Romanticism is linked with the imagination), yet it is a machine, an assemblage of inanimate parts ... " (251-52), which challenges the reality of human subjectivity. The book concludes with Otto maintaining that the panorama changed over the course of the era from simulation to visionary, using Thomas Horner and his "View of London" (1821) as a prime example of the artist as not just an observer but as an adventurer.

By referencing important eighteenth-century philosophical figures such as Kant and Locke as well as modern theorists such as Deleuze and Derrida, Otto reinforces his extensive bibliography with more evidence of his engagement with both historical and modern conceptions of reality. However, while he uses two important women writers, Ann Radcliffe and Mary Shelley, he never actually addresses gender as a potential influence in this concept he has produced, despite there having been extensive work done by feminist and cultural scholars on how vision and perception is gendered, classed, and raced. One notable example is in the very first chapter where 
Otto invokes the prospect view but does not even footnote Jacqueline Labbe's book Romantic Visualities, which aptly genders the prospect view as masculine.

Otto does use revolution (as in the French Revolution) and consumerism as significant implications of his (re)readings of texts, but he never really seems to move beyond the abstract and philosophical. And while his individual readings and use of historical apparatuses are sometimes engaging, his overarching argument seems to be a simple reframing of an old argument where reality is constructed and/or influenced by creativity and imagination. The unique potential for this reframing is, I think, in literature classes, where students would perhaps enjoy the concept of virtual reality. 